\title{
Exploring Water Consumption in Dhaka City Using Instrumental Variables Regression Approaches
}

\author{
Muhammad Shahadat Hossain Siddiquee $^{1,2}$ (D) $\cdot$ Raihan Ahamed $^{1}$
}

Received: 29 April 2020 / Accepted: 4 September 2020/Published online: 24 September 2020

(C) The Author(s) 2020

\begin{abstract}
This paper explores water consumption in Dhaka city for better understanding of its usage, and considers the implications of findings from distributive rationale. Using 459 household survey data collected by BRAC Institute of Governance and Development (BIGD), this study estimates income elasticities of water consumption after controlling the effects of other covariates including wealth-proxies, location, household size, water bill and spatial zones using the instrumental variable regression (IVREG) and instrumental variable quantile regression (IVQREG) approaches. The latter has an additive advantage over the former as the IVQREG provides a more accurate picture of the relationship of water consumption with the income throughout the entire water consumption distribution. Using the fixed pay variable as instrument, findings reveal the strong evidence that income is endogenous. The IVQREG results show that income elasticities are heterogeneous and vary significantly across the water quantiles, implying inequality in water consumption. It also provides strong systematic evidence as income elasticity of water consumption decreases with the increase in percentile. Significant spatial inequality in water consumption from IVREG approach disappears as we use IVQREG. This also strongly supports the systematic evidence obtained. Therefore, it is imperative to introduce different tariff structures among different water consumer groups for bringing equity in water consumption and revenue generation. However, Dhaka Water Supply \& Sewerage Authority (DWASA) must ensure smart water meter before implementing such tariff structure as we face severe challenges while measuring residential water consumption.
\end{abstract}

Keywords Water consumption · Income elasticity · Spatial inequality · Proxy-wealth · IVREG · IVQREG $\cdot$ Dhaka city

Muhammad Shahadat Hossain Siddiquee

siddiquee.econdu@gmail.com

Raihan Ahamed

raihan.bigd@bracu.ac.bd

Extended author information available on the last page of the article 


\section{Introduction}

Dhaka, currently the ninth largest city in the World and projected to be the fourth largest one by 2030 , is the fastest growing and largest urban city in Bangladesh with a population density of 44,500/km² (UN Habitat 2017; United Nations 2018). As per Dhaka Structure Plan (20162035), the projected population of Dhaka city would stand at 22.79 million by 2035. The current evidence shows that one-tenth of the Bangladesh population and a third of its urban population (36\%) live in Dhaka (Bird et al. 2018). Therefore, ensuring equitable and affordable access to water to ever-growing population in Dhaka city has become a growing concern and a big challenge for the Dhaka Water Supply \& Sewerage Authority (henceforth DWASA). For ensuring efficient water distribution, it is imperative for DWASA to realize the consumption variations of its consumers in different income spheres.

Demand-supply gap, quality and equitable distribution of water have become a growing concern in many urban cities of the developing countries like Bangladesh. Moreover, continued growing population in Dhaka city (i.e., rapid urbanization) adds contribution to the imbalances between water demand and supply. Water management policy response to water demand challenges in Dhaka city has become imperative for improving both distributive as well as allocative perspectives. Therefore, it urges to explore the causes of variations in water consumption among the residential water consumers (Schleich and Hillenbrand 2009) using micro-level data. Water policy makers require evidence-based recommendations with a view to devising cost-effective water delivery options for the growing population in Dhaka city.

The estimation of residential water consumption is straightforward as most of the households located in Dhaka city use the single source of water, namely Dhaka Water Supply \& Sewerage Authority (DWASA). Nevertheless, imperfect water price information prevails in the ex post billing in Dhaka city (i.e., fixed pay, household- and holding-wise water meter; combined water usage with enterprises/businesses). However, the basic price theory for water demand from DWASA still holds to some extent. For example, if the water price is fixed (e.g., fixed water bill) and does not depend on the volume of water usages, the marginal price of water usage is zero for all existing consumers. Hence, the law of demand suggests that water use will continue until the marginal utility of water consumption is zero. Hence, preference heterogeneity that persists among the consumers determines the variation in water usage. This also implies weak correlation between fixed pay and water usage. However, this is strongly associated with income. This rational has made us interested in using 'fixed pay for water' an instrumental variable for income. Moreover, this might lead to low price elasticity for residential water demand as well as limited effectiveness and desirability of using price signals as a conservation tool (Gaudin 2006). Therefore, efficient and effective management and expansion of water delivery for the growing Dhaka city requires better understanding of the water usages at the household level (Ahmad et al. 2016). This study aims to contribute in this regard.

Inefficient water usage in Dhaka city is now a major concern, and thus, it requires identifying inefficiencies in water usage with a view to prompting policy response and decision making in regard to efficient water usage to urban households located in Dhaka city. This urges the introduction of efficient water pricing as an economic instrument to improve DWASA infrastructure through revenue generation as well as efficiency in water usage. Rapid urbanization of the Dhaka city is posing many challenges and mounting pressure on existing DWASA infrastructure, water deliveries and water usage. Moreover, the emergence of informal, unplanned and underserviced settlements exacerbates this situation. Therefore, it is of great importance for DWASA authority as a decision maker to provide and manage water 
supply for the growing city of Dhaka. Reconciling the issues like water conservation, efficient usage of water and collecting revenues to cover the costs of water provisioning requires indepth understanding of the consumer's response to income as well as other relevant covariates (Griffin 2006).

This paper contributes to the literature by exploring the income elasticities of water consumption in Dhaka city after controlling the effects of other important covariates of water demand. The micro-level water consumption study used in this paper strives to explore the distributional income effects on water consumption through measuring income elasticities across the water consumption distribution. Moreover, many other proxy-wealth variables such as savings, households owing geyser, shower, high commode, washing machine, water bill and DWASA spatial zones have been considered to check the effects of those covariates on water consumption. Moreover, household size as a demographic variable is used as an explanatory variable. Survey data, collected by BRAC Institute of Governance and Development (BIGD) from 459 households located in Dhaka city, have been used in measuring such estimates.

\section{Empirical Literature on Water Consumption}

Researchers in this field have used and identified different covariates of water consumption including price and non-price measures (i.e., income or wealth, household size and composition, seasonality, precipitation, temperature and locality etc.) using different statistical estimation techniques such as, ordinary least squares (OLS), generalized method of moments (GMM) and quantile regression (Deyà-Tortella et al. 2019; Dikgang et al. 2019; Kumar and Ramachandran 2019; Binet et al. 2014; Cardoso 2013; Wentz and Gober 2007; Worthington and Hoffman 2008). The three most central aspects of empirical works on water consumption are the identification of water demand covariates, nature of water consumption data (i.e., aggregate or household) and the magnitudes of estimated price and income elasticities (Flyr et al. 2019; Oliveira et al. 2017; Sebri 2016; Gardner 2010; Bartczak et al. 2009; Espey et al. 1997; Worthington and Hoffman 2008; Ahmad et al. 2016; Nauges and Thomas 2000; Martínez-Espiñeira 2002; Strand and Walker 2005). Despite different aspects of empirical evidence on water consumption in cities, the common procedure involves identification of most important determinants from a pool of covariates and estimates their separate effects using standard statistical estimation techniques mentioned above.

Among the non-price factors, average income of households appears as a significant determinant of water consumption (Reynaud 2015; Agthe and Billings 1987; Saleth and Dinar 2000; Gaudin et al. 2001; Garcia and Reynaud 2003). This study reviews the empirical evidence in regard to income effects on water consumption, which typically model the divergence between water consumption of the richest and poorest households in respect to their income level differences (Kumar and Ramachandran 2019; Schleich and Hillenbrand 2009; Espey et al. 1997). Empirical evidence shows that though most of the income elasticity estimates are positive, available income data degrades the quality of estimates (Dalhuisen et al. 2003) if income data are collected from public sources (Romano et al. 2016; Bartczak et al. 2009). Most of the recent studies have used the proxy-income variables as a surrogate of real income data for observing their effects on water consumption. This study uses households owing geyser, shower, high commode, washing machine, water bill, and savings as proxywealth variables. Incorporation of household size has extreme importance as it influences 
water consumption. It is evident that the larger household size and the presence of children in the household are positively associated with water consumption (Nauges and Thomas 2000; Cardoso 2013). Population living in spatial zone also affects water consumption and this may be due to the presence of heterogeneous nature of their socio-economic condition. The distributive effects of household income measured in terms of income elasticities have been estimated after controlling the effects of household size, proxy-wealth variables and spatial zones using the cross-sectional data from 459 residential households in Dhaka city. Due to the dearth of facts regarding availability of quality data on water consumption, an empirical analysis of water demand function in developing countries like Bangladesh is less focused. This study aims to contribute in this regard using the most up-to-date computational methods such as instrumental variable linear regression (IVREG) and instrumental variable quantile regression (IVQREG) approaches.

Empirical evidence in this regard is mixed as the studies find different income elasticities of water consumption in the developing countries, and thus, they might have different policy implications for authorities of the water management. The precise and accurate estimation of income elasticities of water consumption plays a great role in devising workable water demand management policies. It would also help contribute to designing efficient water pricing mechanism with a view to reducing the loss of water usage. It also encourages bringing efficiency in production, consumption and sustainability of water availability in the long-run. As multiple factors influence the water consumption, this study analyzes income elasticities of water consumption after controlling the effects of other explanatory variables for different water user groups living in the Dhaka city.

Finally, exploring the diverse water consumer groups requires checking whether elasticity of water consumption varies throughout the entire water consumption distribution. In case of varying income elasticities across the water consumption distribution average income elasticity might fail to provide insightful information on possible effects of income change. As income variable is endogenous, this study applies the instrumental variable quantile regression (IVQREG) to estimate the income elasticities across different quantiles of water consumption distribution in addition to measuring average income elasticity using the instrumental variables regression (IVREG) approach. This would help explain how income elasticities of water consumption differ across the distribution.

Different econometric methods have been applied to explore income elasticities of water consumption at the household level in Dhaka city. There is no published research on estimating income elasticities of water consumption for Dhaka city using the instrumental variables quantile regression (IVQREG) approach. In the quantile regression (QR), pioneered by Koenker and Bassett (1978), each conditional quantile takes linear form representing the relationship between the outcome variable (i.e., water consumption) and the different covariates (e.g., income) at different points of water consumption distribution. As income is endogenous, the IVQREG approach developed by Chernozhukov and Hansen (2006, 2008) has an additive advantage over the IVREG as the IVQREG benefits from being more robust to outliers, more consistent under weaker stochastic assumptions and better picture of the data (Cameron and Trivedi 2005). Introducing IVQREG method into water consumption estimation is of great importance to act upon better characterization of income elasticities and other covariates explaining water consumption in Dhaka city. Findings using the IVQREG estimation would be of great contribution in designing water policies by water management authority of DWASA. 


\section{Data and Methodology}

\subsection{Data}

Dhaka city comprises a total geographical area of $306.38 \mathrm{~km}^{2}$, which is divided into 129 wards for administrative convenience. Presently one-tenth of the Bangladesh population and one third of its urban population (36\%) live in Dhaka (Bird et al. 2018). Dhaka is one of the most densely populated cities in the world with a population density of about 23,234 people $/ \mathrm{km}^{2}$. Water consumption data was collected in 2018 from 459 households located in nine different water zones of the DWASA. The dependent variable used in this study is the per capita per month water consumption. The independent variables include per capita per month income, location (formal settlement vs. slum), wealth-proximate variables, household size, water bill and the DWASA's spatial zones. The descriptive statistics section describes the data in detail.

\subsection{Water Consumption Models for Dhaka City}

\subsubsection{The Instrumental Variable Regression (IVREG) Model}

This section starts with the base Ordinary Least Square (OLS) regression for modeling the estimates of income elasticities, followed by instrumental variables regression (IVREG) and instrumental variables quantile regression (IVQREG) approaches, respectively. As the multiple OLS regression approach inadequately solves the problem of the endogenous explanatory variable (i.e., income), the best approaches are to use instrumental variable regression approaches. Therefore, for our analytical purpose, we model the water consumption using the instrumental variable regression (IVREG) approach in order to study the income elasticity of water consumption at the household level. The econometric models for OLS and IVREG estimations can be expressed as:

$$
O L S: \quad \ln W=\gamma_{0} \ln I+\sum_{i=1}^{k} \gamma_{i} X_{i k}+u_{i k}
$$

2SLS:

$$
\begin{gathered}
\text { Stage 1: } \quad \ln I=\alpha_{0} F P+\sum_{i=1}^{k} \alpha_{i} X_{i k}+v_{i k} \\
\text { Stage 2: } \quad \ln W=\beta_{0} \ln I+\sum_{i=1}^{k} \beta_{i} X_{i k}+\varepsilon_{i k}
\end{gathered}
$$

where $W$ in OLS regression is the vector of $K^{*} 1$ quantities of per capita per month water consumption (L); $I$ is the vector of $K^{*} 1$ per capita monthly income (the variable of our interest to explore); $X_{i k}$ is the vector of control variables including household savings, location (formal settlement vs. slum), household size, wealth proximate dummies like owning shower, washing machine, geyser, high commode, water bill and DWASA zonal dummies; and $u_{i k}$ is the vector of $K^{*} 1$ random errors in Eq. (1). See Table 1 for a description of variables. $\gamma_{0}$ and $\gamma_{i}$ are the vectors of respective parameters of income and other control variables. The estimated 
Table 1 Descriptive statistics and definitions of variables

\begin{tabular}{|c|c|c|c|c|}
\hline Variable name & Variable label & $\begin{array}{l}\text { Mean } \\
\text { (Standard deviation) }\end{array}$ & Min & Max \\
\hline Water & Per capita per month water consumption (L) & $15,103.22(20,074)$ & 404 & 181,818 \\
\hline Income & Per capita per month income $\left(\mathrm{BDT}^{*}\right)$ & $7253.99(5436.28)$ & 1000 & 40,000 \\
\hline Savings & $\begin{array}{l}\text { Savings (=1 if households have savings } \\
\text { and } 0 \text { otherwise) }\end{array}$ & 0.57 & 1 & 0 \\
\hline Location & $\begin{array}{l}\text { Location ( }=1 \text { if households located in } \\
\text { formal settlement and } 0 \text { otherwise) }\end{array}$ & $0.77(0.42)$ & 0 & 1 \\
\hline Household Size & Average number of household members & $4.21(1.59)$ & 1 & 10 \\
\hline Shower & $\begin{array}{l}\text { Shower ( }=1 \text { if household owns shower } \\
\text { and } 0 \text { otherwise) }\end{array}$ & $0.45(0.50)$ & 0 & 1 \\
\hline Washing machine & $\begin{array}{l}\text { Washing machine (=1 if household owns } \\
\text { washing machine and } 0 \text { otherwise) }\end{array}$ & $0.05(0.22)$ & 0 & 1 \\
\hline Geyser & $\begin{array}{l}\text { Geyser ( }=1 \text { if household owns geyser } \\
\text { and } 0 \text { otherwise) }\end{array}$ & $0.03(0.17)$ & 0 & 1 \\
\hline High commode & $\begin{array}{l}\text { High commode (=1 if households has } \\
\text { high commode and } 0 \text { otherwise) }\end{array}$ & $0.26(0.44)$ & 0 & 1 \\
\hline Water bill & Water bill per month (BDT) & $741.51(1579.36)$ & 30 & 27,000 \\
\hline Fixed pay & $\begin{array}{l}\text { Fixed pay ( }=1 \text { if households/holdings without } \\
\text { water meter and pay fixed amount } \\
\text { and } 0 \text { otherwise) }\end{array}$ & $0.49(0.51)$ & 0 & 1 \\
\hline $\mathrm{n}$ & & 459 & - & - \\
\hline
\end{tabular}

Note: Standard deviations are in the parentheses; * implies Bangladeshi Taka (USD 1 = BDT 84.80 as on August $4,2020)$

parameters using the OLS obtain the income elasticity of water consumption (Crane 1994; Rietveld et al. 2000; Basani et al. 2008), which can be estimated directly by taking the partial derivative of the water consumption with respect to income. This takes the form, where $n_{I}$ is the income elasticity of water consumption.

$$
n_{I}=\frac{\partial \ln W}{\partial \ln I}
$$

IVs technique, used to explore whether OLS estimates are unbiased and unobservable related to both income and water consumption, is not standing behind the estimated results (Pokropek 2016). More specifically, socio-demographic characteristics and preference could not be included as control variables in Eq. (1) due to the lack of data. Therefore, there is a possibility that water consumption may be determined by preference and other unobserved factors that are outside the model. These factors are very likely to correlate with income as well. Therefore, the OLS income will pick up some of the effects of the unobserved factors and produce bias estimate. Moreover, self-reported income variable used in the study also suffers from underestimation. This provides motivation for using linear instrumental variable estimation technique (IVREG) to provide a causal interpretation to economic water policy.

The error $u_{i k}$ embodies all factors other than income and other control variables that determine water consumption. One such factor in $u_{i k}$ is fixed pay (FP). Therefore, household or holding under the fixed payment system will induce a correlation between income $(I)$ and error $\left(u_{i k}\right)$ as household or holding with the fixed pay belongs to the category of low income households. This makes the OLS estimator $\widehat{\gamma}_{0}$ inconsistent for $\gamma_{0}$, as $\widehat{\gamma}_{0}$ combines the desired direct effect of income on water consumption $\left(\gamma_{0}\right)$ with the indirect effect that household 
belonging to poor income are likely to have no water meter because of the housing structure and location as well, low $u_{i k}$, and hence, low water consumption.

As income is thought in the study to be endogenous, the inconsistency of $\widehat{\gamma}_{0}$ is referred to as endogeneity bias, which does not disappear asymptotically. This study uses fixed pay dummy as an instrumental variable, which has the property that changes in payment mode are associated with changes in income but do not lead to changes in water consumption in the current settings of Dhaka city. The IV estimator $\widehat{\beta_{0, I V}}$ will be consistent for $\beta_{0}$ provided that the fixed pay (instrument) is uncorrelated with the error $u_{i k}$ and correlated with the income. We argue that in this analysis there is no direct path between fixed pay and water consumption. By doing this we are assuming that household under fixed pay mode does not substantially affect water consumption. However, people with low income and poor housing are more likely to be counted under fixed pay mode and vice versa. The models for IVs estimation are shown in Eqs. (2) and (3).

\subsubsection{The Instrumental Variables Quantile Regression (IVQREG) Model}

Moreover, there is reason to believe that income elasticities using the IVREG might be heterogeneous, that is, income elasticities differ among the different income groups of the households. In addition, income elasticities can vary according to characteristics of the omitted variables such as socio-demographic characteristics and preferences. The IVREG estimator delivers better and reliable estimates in the presence of heterogeneous income elasticities using fixed pay for water as instrumental variable. Before jumping to the IVQREG approach, we briefly describe the quantile regression $(\mathrm{QR})$ first.

Now let us focus on how QR computes several regressions for the different quantiles ranging from 0 to 1 and provides income elasticities after controlling the effects of other control variables on the entire water consumption distribution. This implies an additive advantage over the OLS, which shows how conditional mean value of the dependent variable varies across different covariates. But QR provides more accurate picture of the relationship of the dependent variable, water consumption with the income and other covariates influencing water consumption in Dhaka city. Koenker and Bassett (1978) used the QR in their first seminar paper to explain the usefulness of using QR. However, QR estimates are biased in the presence of endogenous variable, which is income in our case. However, the IVQREG approach can overcome this problem. Now we describe the instrumental variable quantile regression (IVQREG) developed by Chernozhukov and Hansen (2006, 2008).

Conditional on the vector $X=x$, the scalar potential outcome variable of water consumption, $W_{I}$ is given by the quantile function

$$
W_{I}=q\left(I, x, U_{I}\right)
$$

where $q($.$) is a conditional \tau$-quantile function for water consumption; $I$ is a vector of continuous income variable, which is assumed to be endogenous; $x$ denotes the vector of the included exogenous variables such as wealth-proxies, location, household size, water bill and DWASA spatial zones; and $U$ is a non-separable error denoted by $U \mid x$, z uniform $(0,1)$ with $z$ being a vector of the excluded instrument, here it is fixed payment (FP) dummy for water bill.

The endogenous income variable is given by

$$
I=\gamma(X, Z, V)
$$


where $V$ the vector of unobserved variables, which depends on $U$. This paper follows the linear model of the following form to obtain the IVQREG estimator

$$
q(i, x, \tau)=i^{\prime} \gamma(\tau)+\stackrel{\prime}{x} \varnothing(\tau)
$$

We also let $\theta(\tau)=\left\{\gamma(\tau)^{\prime}, \varnothing(\tau)^{\prime}\right\}$. Here, $\gamma$ and $\varnothing$ show the estimated parameters for income and other observable factors after using instrumental variables quantitle regression estimation technique. Endogeneity arises because of the correlation between $I$ and $U$. Conventional quantile regression estimate $\theta(\tau)$ is biased due to endogenous income variable, $I$ (Koenker and Bassett 1978). However, we can overcome this problem using the IV method under certain assumptions (see Chernozhukov and Hansen (2005) for details), which leads to a set of moment conditions as:

$$
P[W \leq q(i, x, \tau) \mid z, x]=\tau
$$

Equation (8) is the main equation for identification as it allows us to estimate $\theta(\tau)$. Moreover, it is used to construct moment conditions for estimating the conditional quantile function of $W$ given $I=i$ and $X=x$. Based on ranking invariance assumption, the even $\{W \leq q(I, x, \tau)\}$ is equivalent to $\{U \leq \tau\}$ and this provides

$$
\underset{\theta(\tau)}{\arg \min } E\left(\rho_{\tau}\left[w-i^{\prime} \gamma(\tau)-x^{\prime} \varnothing(\tau)-\int(z, x)\right]\right)
$$

where $\rho_{\tau}(u)=u[\tau-1(\mathrm{u}<0)]$ and $\int($.$) refers to the general form of F(z, x)$. Eq. (9) refers to the state that 0 is the $\tau$ th quantile of the random variable $W-q(i, x, \tau)$ conditional on $Z=z$ and $X=$ $x$. Solving Eq. (9) would help provide the IVQR estimator for $\theta(\tau)$. The linearity assumption simplifies Eq. (9) as:

$$
\underset{\theta(\tau)}{\arg \min } E\left(\rho_{\tau}\left[w-{ }^{\prime} \gamma(\tau)-\dot{x} \varnothing(\tau)-\dot{z}^{\prime} \pi(\tau)\right]\right)
$$

Instrumental variables quantile regression (IVQREG) uses Eq. (10) to obtain $\widehat{\theta}(\tau)$.

\section{Results}

The empirical results are classified into descriptive statistics, correlation analysis, instrumental variables regression (IVREG) and instrumental variables quantile regression (IVQREG) analyses.

\subsection{Descriptive Statistics}

Table 1 reports the mean and standard deviation of the variables used in the estimation of water consumption model for Dhaka city. Household water consumption is calculated based on water bill paid by the households. The water bill paid by households has been divided by the DWASA tariff rate effective since 1st July 2018 at 11.02 BDT (USD 0.13 ) per $1000 \mathrm{~L}$, to calculate the total water usage of the households per month. For clarity, we excluded the value added tax (VAT) of $15 \%$ from the paid amount for water. 
We calculated the per capita per month water usage by dividing the household per month water usage by the household members assuming each household member uses equal amounts of water. Per capita per month water consumption stands at 15,103 L, with high standard deviation, implying highly skewed water consumption distribution to the right. Average per capita per day water consumption stands at $503 \mathrm{~L}$, which is very high compared to other studies (BIGD 2019; WASA 2016; Abedin and Rakib 2013). Previous studies find that the estimates of per capita per day water consumption in Dhaka city ranges from 250 to $310 \mathrm{~L}$. The high average of water consumption for this study arises because of the following reasons: (a) water bill in some cases in some areas include sewage charges; (b) households using extra pumping machine to bring water often increase the speed of the meter and so it inflates the bill; (c) water bill reported by the owner of a holding, where a single meter is set for the holding, inflates the water bill and thus, the water consumption, and this is a very common scenario in case of water usage in Dhaka city; (d) household water consumption is adulterated with water usage by enterprises/businesses such as restaurants and groceries attached to the households. Such types of cases also inflate water bill as it includes charges for such enterprises. The distribution of $\log$ of per capita per month water consumption seems to be normal (Fig. 1). On average, per capita monthly income stands at BDT 7254 (USD 85.54); 57\% of households have savings; $77 \%$ live in formal settlement; household size stands at 4.21 persons; 45, 5, 3 and 26\% households use shower, washing machine, geyser and high commode, respectively; monthly water bill stands at BDT 742 (USD 8.75); and 49\% of households belong to fixed pay water mode.

\subsection{Correlation Analysis}

Correlation matrix reported Table 2 shows the correlation coefficients between variables. Each cell in the correlation matrix shows the correlation between the two variables. A correlation

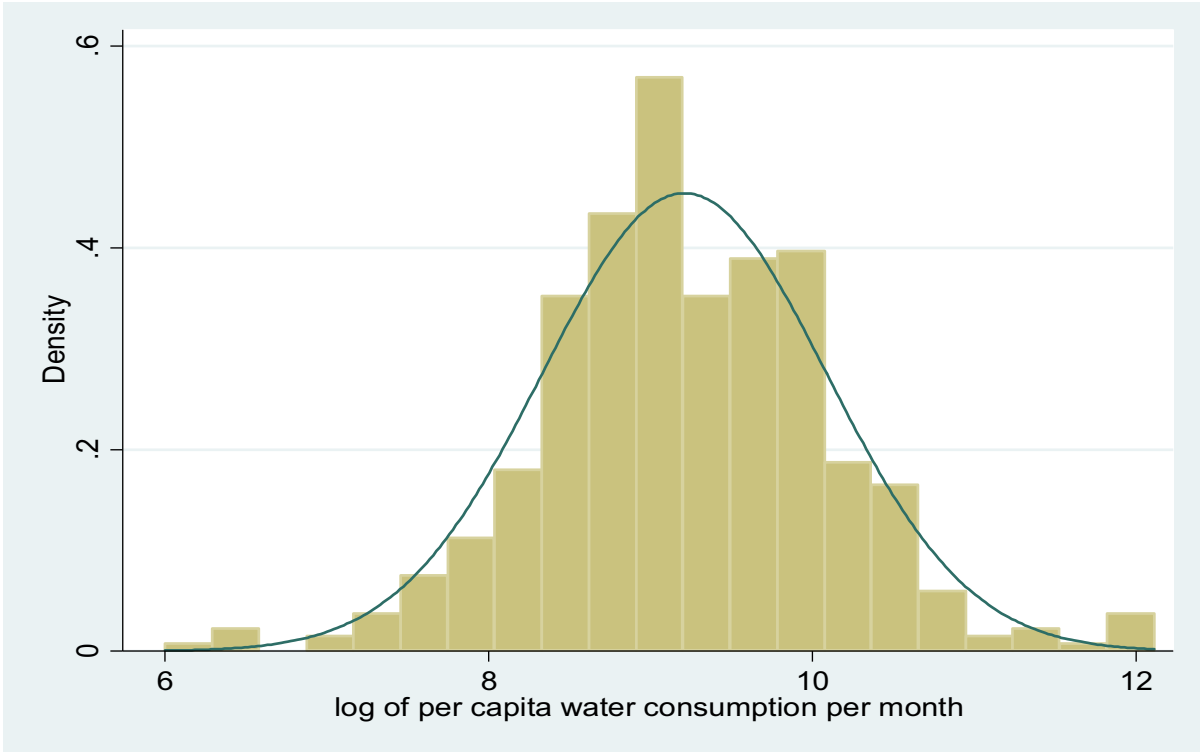

Fig. 1 Normal probability plot of water consumption in Dhaka city 


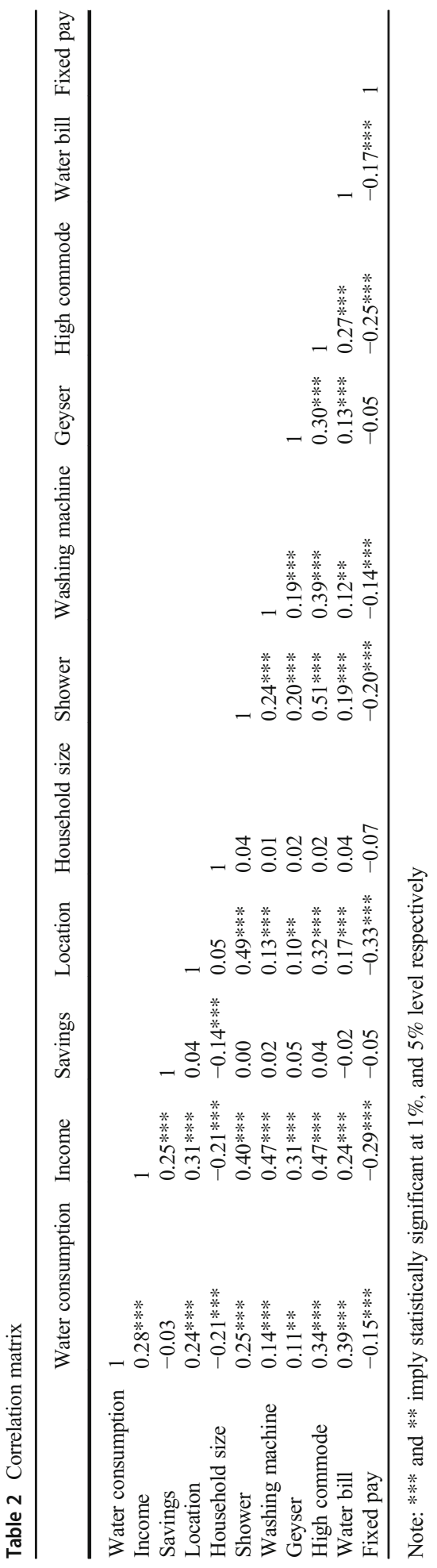


matrix summarizes data and is also used as a diagnostic for advanced analyses including instrumental variables regression models such as IVREG and IVQREG. This study uses correlation analysis as a precursor to the regression models like IVREG and IVQREG in order to identify the strength of linear association between the two variables. Correlation coefficient, $p(x, y)=\frac{\operatorname{Cov}(x, y)}{\sqrt{\operatorname{Var}(x) \operatorname{Var}(y)}}$, ranges from -1 to 1 .

In addition, it is important to examine the presence of multicollinearity in the dataset before applying the desired regression methods. We used it as an initial check to explore the issue of multicollinearity among the covariates since the correlation matrix explains the bivariate linear relationships between variables. Although the correlation matrix is a good detector of multicollinearity, it requires further examination due to multivariate nature of the multicollinearity. Moreover, the correlation matrix of predictors helps to check at a glance how the covariates are associated with the outcome variable as well.

The correlation coefficients reported in Table 2 shows the linear associations between different pairs of variables used in the study. The correlation matrix shows that water consumption is significantly associated with all covariates except savings. It is also observed that water consumption and household size is significantly negatively associated $(-0.21)$. All other variables, except household size and savings, are positively and significantly associated with water consumption. The correlation coefficients reported in Table 2 shows that no issue of multicollinearity persists in the dataset.

\subsection{Instrumental Variable Regression (IVREG) Model for Water Consumption in Dhaka City}

This section presents the OLS estimates of the income elasticities of water along with the results obtained with IVs estimation, which is of our interest, from a comparative perspective. The multiple OLS estimation techniques inadequately address the problems arising from endogenous independent variable "income" as it assumes that covariates included in the OLS regression capture all potential selection (and omitted variables) problems. The OLS approach models the per capita per month water consumption as a function of per capita monthly income, savings, household location (formal settlement vs. slum), household size, and household wealth proximate variables like owning shower, washing machine, geyser and high commode, water bill and DWASA spatial zones. The estimated results using the OLS method are reported in columns $1 \& 2$ of Table 3 with default and robust standard errors respectively. In addition, this study has also applied bootstrapping method for the OLS estimates using 400 replications (column 3 of Table 3).

Let us focus on the estimates of the effects of income (here log of income) on water consumption (log of water consumption) to represent the income elasticity of water consumption. Not surprisingly, income elasticity is positive and statistically significant at $5 \%$ level. All estimates based on log-log model directly measure the elasticities. For example, the coefficient on income is 0.163 , implying that $1 \%$ increase in income causes $0.163 \%$ increase in the quantity of water consumption. After bootstrapping, the income elasticity remains significant at 5\% level with slightly higher standard errors for the income estimate. Similar empirical findings are evident for Ahmad et al. (2016), Stevens et al. (1992), Hoffman et al. (2006), Gaudin (2006), Nauges and Strand (2007), and Schleich and Hillenbrand (2009). Moreover, significantly positive estimate, but small in 
Table 3 Water consumption estimation using OLS and IVREG

\begin{tabular}{|c|c|c|c|c|}
\hline $\begin{array}{l}\text { Dependent variable (log of } \\
\text { water consumption) }\end{array}$ & $\begin{array}{l}\text { (1) OLS } \\
\text { Coefficients } \\
\text { (SEs) }\end{array}$ & $\begin{array}{l}\text { (2) OLS } \\
\text { Coefficients } \\
\text { (Robust SEs) }\end{array}$ & $\begin{array}{l}\text { (3) OLS Coefficients } \\
\text { (Bootstrap SEs) }\end{array}$ & $\begin{array}{l}\text { (4) IVREG } \\
\text { Coefficients (Robust } \\
\text { SEs) }\end{array}$ \\
\hline Log of income & $\begin{array}{l}0.163 * * \\
(0.0728)\end{array}$ & $\begin{array}{l}0.163 * * \\
(0.0724)\end{array}$ & $\begin{array}{l}0.163 * * \\
(0.0752)\end{array}$ & $\begin{array}{l}0.780 * * \\
(0.328)\end{array}$ \\
\hline Savings & $\begin{array}{l}-0.0742 \\
(0.0644)\end{array}$ & $\begin{array}{l}-0.0742 \\
(0.0621)\end{array}$ & $\begin{array}{l}-0.0742 \\
(0.0661)\end{array}$ & $\begin{array}{l}-0.249 * * \\
(0.111)\end{array}$ \\
\hline Location & $\begin{array}{l}0.686 * * * \\
(0.0841)\end{array}$ & $\begin{array}{l}0.686 * * * \\
(0.0875)\end{array}$ & $\begin{array}{l}0.686^{* * * *} \\
(0.109)\end{array}$ & $\begin{array}{l}0.509 * * * \\
(0.122)\end{array}$ \\
\hline Household size & $\begin{array}{l}-0.176^{* * *} \\
(0.0204)\end{array}$ & $\begin{array}{l}-0.176^{* * * *} \\
(0.0243)\end{array}$ & $\begin{array}{l}-0.176^{* * *} \\
(0.0236)\end{array}$ & $\begin{array}{l}-0.104 * * \\
(0.0453)\end{array}$ \\
\hline Shower & $\begin{array}{l}0.187 * * \\
(0.0777)\end{array}$ & $\begin{array}{l}0.187 * * \\
(0.0832)\end{array}$ & $\begin{array}{l}0.187 * * \\
(0.0759)\end{array}$ & $\begin{array}{l}0.0371 \\
(0.120)\end{array}$ \\
\hline Washing machine & $\begin{array}{l}0.0719 \\
(0.149)\end{array}$ & $\begin{array}{l}0.0719 \\
(0.162)\end{array}$ & $\begin{array}{l}0.0719 \\
(0.172)\end{array}$ & $\begin{array}{l}-0.239 \\
(0.265)\end{array}$ \\
\hline Geyser & $\begin{array}{l}-0.0830 \\
(0.180)\end{array}$ & $\begin{array}{l}-0.0830 \\
(0.277)\end{array}$ & $\begin{array}{l}-0.0830 \\
(0.311)\end{array}$ & $\begin{array}{l}-0.223 \\
(0.307)\end{array}$ \\
\hline High commode & $\begin{array}{l}0.199 * * \\
(0.0884)\end{array}$ & $\begin{array}{l}0.199 * \\
(0.105)\end{array}$ & $\begin{array}{l}0.199 * \\
(0.114)\end{array}$ & $\begin{array}{l}0.0203 \\
(0.148)\end{array}$ \\
\hline Water bill & $\begin{array}{l}0.000119 * * * \\
(1.99 \mathrm{e}-05)\end{array}$ & $\begin{array}{l}0.000119 \\
(7.78 \mathrm{e}-05)\end{array}$ & $\begin{array}{l}0.000119 \\
(0.000184)\end{array}$ & $\begin{array}{l}0.000104 \\
(7.50 \mathrm{e}-05)\end{array}$ \\
\hline \multicolumn{5}{|c|}{ DWASA Zone (Reference zone: DWASA Zone 5$)^{+}$} \\
\hline DWASA Zone 1 & $\begin{array}{l}-0.438 * * * \\
(0.153)\end{array}$ & $\begin{array}{l}-0.438^{* *} \\
(0.189)\end{array}$ & $\begin{array}{l}-0.438^{*} \\
(0.232)\end{array}$ & $\begin{array}{l}-0.362 * \\
(0.212)\end{array}$ \\
\hline DWASA Zone 2 & $\begin{array}{l}-0.418 * * * \\
(0.158)\end{array}$ & $\begin{array}{l}-0.418^{* *} \\
(0.193)\end{array}$ & $\begin{array}{l}-0.418 * \\
(0.246)\end{array}$ & $\begin{array}{l}-0.276 \\
(0.225)\end{array}$ \\
\hline DWASA Zone 3 & $\begin{array}{l}-0.152 \\
(0.151)\end{array}$ & $\begin{array}{l}-0.152 \\
(0.179)\end{array}$ & $\begin{array}{l}-0.152 \\
(0.193)\end{array}$ & $\begin{array}{l}-0.0646 \\
(0.198)\end{array}$ \\
\hline DWASA Zone 4 & $\begin{array}{l}-0.742 * * * \\
(0.142)\end{array}$ & $\begin{array}{l}-0.742 * * * \\
(0.197)\end{array}$ & $\begin{array}{l}-0.742 * * * \\
(0.261)\end{array}$ & $\begin{array}{l}-0.624 * * * \\
(0.222)\end{array}$ \\
\hline DWASA Zone 6 & $\begin{array}{l}-0.545^{* * * *} \\
(0.142)\end{array}$ & $\begin{array}{l}-0.545^{* * * *} \\
(0.170)\end{array}$ & $\begin{array}{l}-0.545 * * \\
(0.229)\end{array}$ & $\begin{array}{l}-0.448^{* *} \\
(0.193)\end{array}$ \\
\hline DWASA Zone 8 & $\begin{array}{l}-0.546 * * * \\
(0.153)\end{array}$ & $\begin{array}{l}-0.546^{* * * *} \\
(0.203)\end{array}$ & $\begin{array}{l}-0.546 * * \\
(0.263)\end{array}$ & $\begin{array}{l}-0.522 * * \\
(0.215)\end{array}$ \\
\hline DWASA Zone 9 & $\begin{array}{l}-0.736^{* * *} \\
(0.145)\end{array}$ & $\begin{array}{l}-0.736^{* * * *} \\
(0.170)\end{array}$ & $\begin{array}{l}-0.736 * * * \\
(0.247)\end{array}$ & $\begin{array}{l}-0.690 * * * \\
(0.182)\end{array}$ \\
\hline DWASA Zone 10 & $\begin{array}{l}-0.712 * * * \\
(0.143)\end{array}$ & $\begin{array}{l}-0.712 * * * \\
(0.165)\end{array}$ & $\begin{array}{l}-0.712 * * * \\
(0.241)\end{array}$ & $\begin{array}{l}-0.593 * * * \\
(0.191)\end{array}$ \\
\hline Constant & $\begin{array}{l}8.357 * * * \\
(0.652)\end{array}$ & $\begin{array}{l}8.357 * * * \\
(0.652)\end{array}$ & $\begin{array}{l}8.357 * * * \\
(0.667)\end{array}$ & $\begin{array}{l}2.981 \\
(2.879)\end{array}$ \\
\hline Observations & 459 & 459 & 459 & 459 \\
\hline R-squared & 0.518 & 0.518 & 0.518 & 0.439 \\
\hline F Statistic & $27.84 * * *$ & $29.14 * * *$ & - & - \\
\hline Wald Chi2 (17) & - & - & $526.11 * * *$ & $446.85 * * *$ \\
\hline
\end{tabular}

Notes: Standard errors (SEs), robust SEs and bootstrap SEs in parentheses; + No sample data from DWASA Zone 7 ; *** $p<0.01$, ** $p<0.05$, * $p<0.1$; Values of variance inflation factor (VIF) ranges from 2.98 to 1.14 and the mean VIF of the model stands at 2.02, which is much below the cut-off points of 5, 10 or above, implying no multicollinearity problem; Instrumented: income

magnitude, of income elasticity implies inelastic responsiveness to water consumption due to change in income.

By using a two-sided test at level 0.05 for OLS, location, household size, shower and high commode are individually statistically significant as $p<0.10$. After applying the bootstrapping method with 400 replications, these estimated coefficients remain 
statistically significant. In addition, other wealth-proxies like savings, washing machine and geyser have insignificant effect on water consumption and this may be due to small sample for the designated wealth-proxies as well as the inclusion of several wealthproxies in regression specification that capture well the water consumption effects of these variables. Similarly, this study finds no significant effect of water bill. The dependent variable, water consumption, also displays a spatial (or zonal) distribution with the highest water consumption in Zone 5 of DWASA, which is dominated by large and expensive homes. This indicates the presence of spatial inequality in water consumption in Dhaka city.

As the multiple OLS estimation techniques inadequately address the problems of endogenous independent variable "income" and make the OLS estimates biased, we use IV technique to examine this issue using fixed pay dummy as an instrument for income. Fixed pay variable is expected to be connected with the income and it should not be causally related with water consumption. This analysis argues that there is no direct path between fixed pay and water consumption. By doing so, we are assuming that household or holding with and without fixed pay does not substantially affect water consumption in Dhaka city. It is likely to be true as fixed pay is measured in dummy rather than quantities (it is around $49 \%$ households under the fixed pay mode).

The Stage 1 Eq. (2) cleans up the endogenous predictor income, leaving only the exogenous part of the variation that covaries with the instrument, fixed pay in our case. The Stage 2 Eq. (3) is very identical to an OLS Eq. (1) except that predicted income variable $\hat{\imath} I$ is cleaned up by the instrument of fixed pay in Stage 1 . This allows to estimate the causal relationship of income with water consumption. Table 4 shows the results of the first stage of 2 SLS described by Eq. (2). The first stage regression has satisfactory explanatory power, and the coefficient of fixed pay is negative, as expected, and highly statistically significant. It plays an important role for the study as the instrumental variable "fixed pay" is highly significantly related with the instrumented variable "income".

Table 4 First-stage regression results of the IVREG and IVQREG

\begin{tabular}{|c|c|c|c|c|c|}
\hline $\begin{array}{l}\text { Log of } \\
\text { Income: } \\
\text { dependent } \\
\text { variable }\end{array}$ & $\begin{array}{l}\text { (1) REG } \\
\text { Coefficients } \\
\text { (Robust SEs) }\end{array}$ & $\begin{array}{l}\text { (2) } \mathrm{SQREG}_{0.25} \\
\text { Coefficients } \\
\text { (Bootstrap SEs) }\end{array}$ & $\begin{array}{l}\text { (3) } \mathrm{SQREG}_{0.50} \\
\text { Coefficients } \\
\text { (Bootstrap SEs) }\end{array}$ & $\begin{array}{l}\text { (4) } \mathrm{SQREG}_{0.75} \\
\text { Coefficients } \\
\text { (Bootstrap SEs) }\end{array}$ & $\begin{array}{l}\text { (5) } \mathrm{SQREG}_{0.85} \\
\text { Coefficients } \\
\text { (Bootstrap SEs) }\end{array}$ \\
\hline Fixed pay & $\begin{array}{l}-0.204 * * * \\
(0.0436)\end{array}$ & $\begin{array}{l}-0.207 \text { *** } \\
(0.0655)\end{array}$ & $\begin{array}{l}-0.277 * * * \\
(0.0570)\end{array}$ & $\begin{array}{l}-0.244 * * * \\
(0.0513)\end{array}$ & $\begin{array}{l}-0.208 * * * \\
(0.0789)\end{array}$ \\
\hline Savings & $\begin{array}{l}0.272 * * * \\
(0.0403)\end{array}$ & $\begin{array}{l}0.298 * * * \\
(0.0525)\end{array}$ & $\begin{array}{l}0.280 * * * \\
(0.0460)\end{array}$ & $\begin{array}{l}0.204 * * * \\
(0.0421)\end{array}$ & $\begin{array}{l}0.300 * * * \\
(0.0806)\end{array}$ \\
\hline Location & $\begin{array}{l}0.221 * * * \\
(0.0474)\end{array}$ & $\begin{array}{l}0.163 * * * \\
(0.0545)\end{array}$ & $\begin{array}{l}0.161 * * * \\
(0.0407)\end{array}$ & $\begin{array}{l}0.180 * * \\
(0.0746)\end{array}$ & $\begin{array}{l}0.263 * * \\
(0.123)\end{array}$ \\
\hline $\begin{array}{l}\text { Household } \\
\text { size }\end{array}$ & $\begin{array}{l}-0.121 \text { *** } \\
(0.0140)\end{array}$ & $\begin{array}{l}-0.137 \text { *** } \\
(0.0188)\end{array}$ & $\begin{array}{l}-0.118^{* * *} \\
(0.0127)\end{array}$ & $\begin{array}{l}-0.130 * * * \\
(0.0164)\end{array}$ & $\begin{array}{l}-0.121 * * * \\
(0.0167)\end{array}$ \\
\hline Shower & $\begin{array}{l}0.244 * * * \\
(0.0555)\end{array}$ & $\begin{array}{l}0.250 * * * \\
(0.0544)\end{array}$ & $\begin{array}{l}0.323 * * * \\
(0.0519)\end{array}$ & $\begin{array}{l}0.399 * * * \\
(0.0897)\end{array}$ & $\begin{array}{l}0.334 * * * \\
(0.104)\end{array}$ \\
\hline $\begin{array}{l}\text { Washing } \\
\text { machine }\end{array}$ & $\begin{array}{l}0.474 * * * \\
(0.102)\end{array}$ & $\begin{array}{l}0.375^{* *} \\
(0.177)\end{array}$ & $\begin{array}{l}0.474 * * * \\
(0.0851)\end{array}$ & $\begin{array}{l}0.615 * * \\
(0.241)\end{array}$ & $\begin{array}{l}0.662 * * * \\
(0.251)\end{array}$ \\
\hline Geyser & $0.251^{*}$ & 0.121 & 0.234 & 0.300 & 0.266 \\
\hline
\end{tabular}


Table 4 (continued)

\begin{tabular}{|c|c|c|c|c|c|}
\hline $\begin{array}{l}\text { Log of } \\
\text { Income: } \\
\text { dependent } \\
\text { variable }\end{array}$ & $\begin{array}{l}\text { (1) REG } \\
\text { Coefficients } \\
\text { (Robust SEs) }\end{array}$ & $\begin{array}{l}\text { (2) } \mathrm{SQREG}_{0.25} \\
\text { Coefficients } \\
\text { (Bootstrap SEs) }\end{array}$ & $\begin{array}{l}\text { (3) } \mathrm{SQREG}_{0.50} \\
\text { Coefficients } \\
\text { (Bootstrap SEs) }\end{array}$ & $\begin{array}{l}\text { (4) } \mathrm{SQREG}_{0.75} \\
\text { Coefficients } \\
\text { (Bootstrap SEs) }\end{array}$ & $\begin{array}{l}\text { (5) } \text { SQREG }_{0.85} \\
\text { Coefficients } \\
\text { (Bootstrap SEs) }\end{array}$ \\
\hline & $(0.139)$ & $(0.152)$ & $(0.149)$ & $(0.286)$ & $(0.281)$ \\
\hline High & $0.261 * * *$ & $0.305 * * *$ & $0.244 * * *$ & $0.163 *$ & $0.232 * *$ \\
\hline commode & $(0.0524)$ & $(0.0574)$ & $(0.0788)$ & $(0.0955)$ & $(0.0977)$ \\
\hline Water bill & $\begin{array}{l}1.97 \mathrm{e}-05^{* *} \\
(8.30 \mathrm{e}-06)\end{array}$ & $\begin{array}{l}1.86 \mathrm{e}-05 \\
(2.61 \mathrm{e}-05)\end{array}$ & $\begin{array}{l}1.18 \mathrm{e}-05 \\
(1.48 \mathrm{e}-05)\end{array}$ & $\begin{array}{l}1.65 e-05 \\
(1.85 e-05)\end{array}$ & $\begin{array}{l}-1.75 \mathrm{e}-06 \\
(1.80 \mathrm{e}-05)\end{array}$ \\
\hline \multicolumn{6}{|c|}{ DWASA Zone (Reference zone: DWASA Zone 5$)^{+}$} \\
\hline DWASA & -0.0961 & -0.0249 & -0.113 & $-0.267 * *$ & -0.138 \\
\hline Zone 1 & $(0.107)$ & $(0.132)$ & $(0.0921)$ & $(0.104)$ & $(0.175)$ \\
\hline DWASA & $-0.226^{*}$ & -0.248 & $-0.275^{*}$ & -0.129 & 0.0903 \\
\hline Zone 2 & $(0.121)$ & $(0.198)$ & $(0.165)$ & $(0.192)$ & $(0.189)$ \\
\hline DWASA & -0.120 & -0.149 & -0.107 & -0.217 & -0.157 \\
\hline Zone 3 & $(0.0866)$ & $(0.156)$ & $(0.0861)$ & $(0.143)$ & $(0.235)$ \\
\hline DWASA & $-0.142 *$ & -0.0972 & -0.0807 & $-0.224 * *$ & -0.158 \\
\hline Zone 4 & $(0.0771)$ & $(0.148)$ & $(0.100)$ & $(0.0896)$ & $(0.124)$ \\
\hline DWASA & $-0.128 *$ & -0.0410 & -0.118 & $-0.261 * *$ & $-0.240 *$ \\
\hline Zone 6 & $(0.0708)$ & $(0.147)$ & $(0.0946)$ & $(0.105)$ & $(0.145)$ \\
\hline DWASA & -0.0475 & -0.101 & -0.00770 & 0.0152 & 0.0698 \\
\hline Zone 8 & $(0.0885)$ & $(0.155)$ & $(0.134)$ & $(0.127)$ & $(0.139)$ \\
\hline DWASA & -0.0538 & -0.0418 & 0.00698 & -0.132 & -0.143 \\
\hline Zone 9 & $(0.0750)$ & $(0.135)$ & $(0.103)$ & $(0.0803)$ & $(0.129)$ \\
\hline DWASA & $-0.134 *$ & -0.0700 & -0.110 & $-0.251 * *$ & -0.190 \\
\hline Zone 10 & $(0.0725)$ & $(0.148)$ & $(0.0903)$ & $(0.101)$ & $(0.134)$ \\
\hline \multirow[t]{2}{*}{ Constant } & $8.661 * * *$ & $8.712 * * *$ & $8.879 * * *$ & $9.223 * * *$ & $9.159 * * *$ \\
\hline & $(0.0895)$ & $(0.207)$ & $(0.0977)$ & $(0.129)$ & $(0.168)$ \\
\hline Observations & 459 & 459 & 459 & 459 & 459 \\
\hline R-squared & 0.586 & 0.388 & 0.423 & 0.423 & 0.412 \\
\hline F Statistic & $45.04 * * *$ & - & - & - & - \\
\hline
\end{tabular}

Notes: Robust standard errors and bootstrap standard errors in parentheses; + No sample data from DWASA Zone 7 ; *** $p<0.01, * * p<0.05, * p<0.1$;

Column 4 of Table 3 reports the results obtained using the second stage of the 2SLS estimation of Eq. (3). Estimates based on the IVs reveal that income elasticity of water consumption is positive, as expected, and statistically significant even at 5\% level and income has bigger responsiveness on water consumption than the OLS estimate. For example, the estimated coefficient of income now is 0.78 , implying $0.78 \%$ increase in water consumption due to $1 \%$ increase in income. As IV provides only local average treatment effect (LATE), it is possible that the income elasticity is heterogeneous. It implies that responsiveness of water consumption might vary with the different income groups. The general perception in this regard is that responsiveness would be low with the people in richer income groups as they consume already significantly more compared to the poorer groups. Therefore, we use the instrumental variable quantile regression (IVQREG) approach as it accounts for this heterogeneity while estimating income elasticity across the water consumption distribution (discussed later on the section). However, note that results obtained using the IVREG do not reverse the sign of the effects of the significant covariates reported in Table 3, and thus, interpretation of the results remain the same. However, the coefficient of savings also changes from 
insignificant to significant. The standard error of the instrumented regressor 'income' increases from 0.072 to 0.328 , implying the potential loss in efficiency due to using the IV approach.

This study also uses the Wald test to test the equality of the coefficients of interest. The F statistics version of the Wald test has been used after the IVREG regression estimation for water consumption. A common test is one of the equality of coefficients of the covariates. For example, this study tests that the households located in different DWASA spatial zones have the same effects on water consumption. The test of

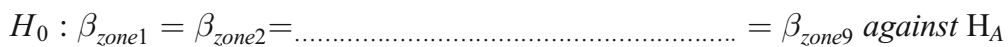

$$
\begin{aligned}
& : \beta_{\text {zone } 1} \neq \beta_{\text {zone } 2} \neq \ldots \ldots \ldots \ldots \ldots \ldots \ldots \ldots \ldots \ldots \ldots \ldots \ldots \text { zone } 9
\end{aligned}
$$

has been performed to check whether coefficients of the DWASA zones vary significantly or not. Water consumption estimates of the DWASA zones are jointly statistically significant as the overall Chi2 statistic is 31.90 with a $p$ value of 0.000 . This implies that significant variations (i.e., spatial inequality) in water consumption persists across the water zones in Dhaka city, implying spatial inequality in water consumption.

The preceding analysis treats the income variable as endogenous. As the results obtained using the IVREG and OLS approaches differ considerably, this is a strong evidence that income is endogenous. Moreover, this study applies the Durbin-WuHausman (DWH) test to examine endogeneity as it produces robust test statistics using the device of augmented regressors (Davidson 2000). The robustified DWH test statistic leads to strong rejection of the null hypothesis that income is exogenous. Therefore, we conclude that income is endogenous. Now our concern is to check whether the instrument 'fixed payment' is weak as it provides a poor guide to actual finite sample distributions. This study diagnoses it using pairwise correlation between endogenous regressor (income) and instrument (fixed payment). The estimated correlation coefficient is -0.28 , which is not so low to treat this as weak instrument. Moreover, there will be no considerable loss of precision using the IV estimation as the first two statistics, $\mathrm{R}^{2}$ and adjusted $\mathrm{R}^{2}$, are found around 0.59 and 0.57 respectively, which are high. F-test on just fixed pay (instrument) find the value of 21.92, which is considerably larger than the rule of thumb value of 10 . Therefore, fixed pay does seem to be a strong instrument.

\subsection{Instrumental Variable Quantile Regression (IVQREG) Model for Water Consumption in Dhaka City}

The IVQREG estimator delivers a reliable estimate for the endogenous and heterogenous income elasticities using fixed pay dummy as instrument. Since the sample data collection is random in our case, we can use fixed pay as an instrument for the income. Due to fixed payment nature of water consumption, we are fortunate to have low and high correlations of the instrument with water consumption and income, respectively. The IVQREG results using fixed pay dummy as an instrument are reported in Table 5. The output reported in Table 5 shows the estimated coefficients for different quantiles at $\mathrm{QR}_{25}, \mathrm{QR}_{50}, \mathrm{QR}_{75}$, and $\mathrm{QR}_{85}$ in addition to IVREG estimates.

Table 5, columns 2-5, report the coefficient estimates and bootstrap standard errors in the parentheses at quantiles $\mathrm{QR}_{0.25}, \mathrm{QR}_{0.50}, \mathrm{QR}_{0.75}$ and $\mathrm{QR}_{0.85}$. The output reported in 
Table 5 Estimates of income elasticities of water consumption using IVREG and IVQREG

\begin{tabular}{|c|c|c|c|c|c|}
\hline $\begin{array}{l}\text { Dependent } \\
\text { variable (log of } \\
\text { water } \\
\text { consumption) }\end{array}$ & $\begin{array}{l}\text { (1) IVREG } \\
\text { Coefficients } \\
\text { (Robust SEs) }\end{array}$ & $\begin{array}{l}\text { (2) } \text { IVQREG }_{0.25} \\
\text { Coefficients } \\
\text { (Bootstrap SEs) }\end{array}$ & $\begin{array}{l}\text { (3) } \text { IVQREG }_{0.50} \\
\text { Coefficients } \\
\text { (Bootstrap SEs) }\end{array}$ & $\begin{array}{l}\text { (4) } \text { IVQREG }_{0.75} \\
\text { Coefficients } \\
\text { (Bootstrap SEs) }\end{array}$ & $\begin{array}{l}\text { (5) IVQREG } \\
\text { Coefficients } \\
\text { (Bootstrap SEs) }\end{array}$ \\
\hline Log of income & $\begin{array}{c}0.780 * * \\
(0.328)\end{array}$ & $\begin{array}{c}0.922 * * \\
(0.372)\end{array}$ & $\begin{array}{c}0.880^{* * * *} \\
(0.225)\end{array}$ & $\begin{array}{c}0.577 * * * \\
(0.209)\end{array}$ & $\begin{array}{l}0.352^{*} \\
(0.207)\end{array}$ \\
\hline Savings & $\begin{array}{c}-0.249 * * \\
(0.111)\end{array}$ & $\begin{array}{c}-0.262 * \\
(0.135)\end{array}$ & $\begin{array}{c}-0.265 * * * \\
(0.0827)\end{array}$ & $\begin{array}{c}-0.203 * * * \\
(0.0696)\end{array}$ & $\begin{array}{l}-0.130 * \\
(0.0698)\end{array}$ \\
\hline Location & $\begin{array}{c}0.509 * * * \\
(0.122)\end{array}$ & $\begin{array}{c}0.263 \\
(0.167)\end{array}$ & $\begin{array}{c}0.278 * * * \\
(0.0783)\end{array}$ & $\begin{array}{c}0.360 * * * \\
(0.0888)\end{array}$ & $\begin{array}{c}0.265^{* * *} * \\
(0.0985)\end{array}$ \\
\hline Household size & $\begin{array}{c}-0.104 * * \\
(0.0453)\end{array}$ & $\begin{array}{l}-0.0891 \\
(0.0556)\end{array}$ & $\begin{array}{c}-0.0799 * * \\
(0.0365)\end{array}$ & $\begin{array}{c}-0.128 * * * \\
(0.0352)\end{array}$ & $\begin{array}{c}-0.159 * * * \\
(0.0354)\end{array}$ \\
\hline Shower & $\begin{array}{l}0.0371 \\
(0.120)\end{array}$ & $\begin{array}{l}0.0373 \\
(0.129)\end{array}$ & $\begin{array}{l}-0.0986 \\
(0.0809)\end{array}$ & $\begin{array}{l}-0.105^{*} \\
(0.0570)\end{array}$ & $\begin{array}{l}-0.0754 \\
(0.0591)\end{array}$ \\
\hline Washing machine & $\begin{array}{l}-0.239 \\
(0.265)\end{array}$ & $\begin{array}{l}-0.331 \\
(0.202)\end{array}$ & $\begin{array}{c}-0.243 * * \\
(0.114)\end{array}$ & $\begin{array}{c}-0.216^{* *} \\
(0.0848)\end{array}$ & $\begin{array}{l}-0.135 \\
(0.0990)\end{array}$ \\
\hline Geyser & $\begin{array}{l}-0.223 \\
(0.307)\end{array}$ & $\begin{array}{l}-0.207 \\
(0.406)\end{array}$ & $\begin{array}{c}-0.0945 \\
(0.153)\end{array}$ & $\begin{array}{l}-0.0757 \\
(0.0786)\end{array}$ & $\begin{array}{l}-0.0941 \\
(0.0687)\end{array}$ \\
\hline High commode & $\begin{array}{l}0.0203 \\
(0.148)\end{array}$ & $\begin{array}{l}-0.117 \\
(0.201)\end{array}$ & $\begin{array}{c}-0.198^{* *} \\
(0.0893)\end{array}$ & $\begin{array}{c}-0.116 \\
(0.0746)\end{array}$ & $\begin{array}{r}-0.0424 \\
(0.0709)\end{array}$ \\
\hline Water bill & $\begin{array}{c}0.000104 \\
(7.50 \mathrm{e}-05)\end{array}$ & $\begin{array}{c}0.000373 \\
(0.000292)\end{array}$ & $\begin{array}{c}0.000747 * * * \\
(0.000204)\end{array}$ & $\begin{array}{c}0.000957 * * * \\
(0.000171)\end{array}$ & $\begin{array}{c}0.00105 * * * \\
(0.000167)\end{array}$ \\
\hline \multicolumn{6}{|c|}{ DWASA Zone (Reference zone: DWASA Zone 5) ${ }^{+}$} \\
\hline DWASA Zone 1 & $\begin{array}{c}-0.362 * \\
(0.212)\end{array}$ & $\begin{array}{l}-0.114 \\
(0.276)\end{array}$ & $\begin{array}{c}0.00352 \\
(0.149)\end{array}$ & $\begin{array}{c}-0.00205 \\
(0.125)\end{array}$ & $\begin{array}{c}-0.0639 \\
(0.127)\end{array}$ \\
\hline DWASA Zone 2 & $\begin{array}{l}-0.276 \\
(0.225)\end{array}$ & $\begin{array}{l}0.0853 \\
(0.298)\end{array}$ & $\begin{array}{c}0.169 \\
(0.158)\end{array}$ & $\begin{array}{l}0.0834 \\
(0.150)\end{array}$ & $\begin{array}{c}-0.0229 \\
(0.161)\end{array}$ \\
\hline DWASA Zone 3 & $\begin{array}{c}-0.0646 \\
(0.198)\end{array}$ & $\begin{array}{l}0.0650 \\
(0.208)\end{array}$ & $\begin{array}{l}0.0526 \\
(0.133)\end{array}$ & $\begin{array}{l}0.0136 \\
(0.138)\end{array}$ & $\begin{array}{c}-0.0972 \\
(0.149)\end{array}$ \\
\hline DWASA Zone 4 & $\begin{array}{c}-0.624 * * * \\
(0.222)\end{array}$ & $\begin{array}{c}-0.564 * * \\
(0.266)\end{array}$ & $\begin{array}{l}-0.132 \\
(0.184)\end{array}$ & $\begin{array}{c}-0.0858 \\
(0.134)\end{array}$ & $\begin{array}{c}-0.0758 \\
(0.141)\end{array}$ \\
\hline DWASA Zone 6 & $\begin{array}{c}-0.448 * * \\
(0.193)\end{array}$ & $\begin{array}{c}-0.0671 \\
(0.227)\end{array}$ & $\begin{array}{c}-0.0679 \\
(0.150)\end{array}$ & $\begin{array}{l}-0.125 \\
(0.124)\end{array}$ & $\begin{array}{l}-0.179 \\
(0.114)\end{array}$ \\
\hline DWASA Zone 8 & $\begin{array}{c}-0.522 * * \\
(0.215)\end{array}$ & $\begin{array}{l}-0.384 \\
(0.312)\end{array}$ & $\begin{array}{l}0.0336 \\
(0.176)\end{array}$ & $\begin{array}{c}-0.0104 \\
(0.124)\end{array}$ & $\begin{array}{c}-0.0838 \\
(0.133)\end{array}$ \\
\hline DWASA Zone 9 & $\begin{array}{c}-0.690 * * * \\
(0.182)\end{array}$ & $\begin{array}{l}-0.291 \\
(0.255)\end{array}$ & $\begin{array}{l}-0.152 \\
(0.163)\end{array}$ & $\begin{array}{l}-0.132 \\
(0.129)\end{array}$ & $\begin{array}{c}-0.214 * \\
(0.126)\end{array}$ \\
\hline $\begin{array}{l}\text { DWASA Zone } \\
\quad 10\end{array}$ & $\begin{array}{c}-0.593 * * * \\
(0.191)\end{array}$ & $\begin{array}{c}-0.171 \\
(0.254)\end{array}$ & $\begin{array}{l}-0.133 \\
(0.166)\end{array}$ & $\begin{array}{l}-0.140 \\
(0.130)\end{array}$ & $\begin{array}{c}-0.225^{*} \\
(0.131)\end{array}$ \\
\hline Constant & $\begin{array}{c}2.981 \\
(2.879)\end{array}$ & $\begin{array}{c}1.438 \\
(3.190)\end{array}$ & $\begin{array}{c}1.775 \\
(1.905)\end{array}$ & $\begin{array}{c}4.466 * * \\
(1.783)\end{array}$ & $\begin{array}{c}6.581 * * * \\
(1.777)\end{array}$ \\
\hline Observations & 459 & 459 & 459 & 459 & 459 \\
\hline $\mathrm{R}^{2} /$ Pseudo $\mathrm{R}^{2}$ & 0.439 & 0.336 & 0.466 & 0.573 & 0.610 \\
\hline
\end{tabular}

Note: Robust and bootstrap standard errors from 400 replications in parentheses: *** $p<0.01, * * p<0.05, * p<0.1$

column 3 of Table 5 shows the coefficient estimate for water consumption at the median quantile $\mathrm{QR}_{0.50}$. The income elasticity for the households with median water consumption is 0.88 (i.e., income elasticity at 50 th percentile is 0.88 ). The estimated coefficients of all the independent variables represent marginal effects for the households with median water consumption. We use bootstrap standard errors assuming that the errors vary with the covariates. For example, the variance of income possibly varies with wealth-proximate variables. Income elasticity decreases from 0.92 at $\mathrm{QR}_{0.25}$ to 0.35 at $\mathrm{QR}_{0.85}$. The income elasticities at different quantiles are positive and statistically significant. The IVREG estimate of income (i.e., 0.78) differs considerably from the IVQREG 
coefficients, even those for median regression (i.e., $\mathrm{QR}_{0.50}$ ). The income elasticities for the households with median water consumption is 0.88 , which is income inelastic. The substantive interpretation is that median household water consumption increases by $0.88 \%$ due to $1 \%$ increase in their income. The IVQREG estimates of income elasticities imply systematic evidence across the water consumption distribution in Dhaka city. More specifically, the income elasticity of water consumption decreases with the increase in percentile. Findings also imply that income elasticity estimate converges to other global estimates as we move from lower water consumption quantile to higher water consumption quantile. The true reflection of the global estimates arises for households belonging to the higher quantiles of water consumption in our case. Note that presence of water is significantly higher among the water richest households compared with the water poorest households, and thus, it becomes possible to have globally comparable estimates for the water richest households in Dhaka city.

One reason for income elasticities differing across quantiles is the presence of heteroskedastic errors. It is also possible to conduct hypothesis tests of equality of the income elasticities at different conditional quantiles of water consumption. The test of the equality of the income elasticities from the $\mathrm{QR}_{0.25}, \mathrm{QR}_{0.50}, \mathrm{QR}_{0.75}$ and $\mathrm{QR}_{0.85}$ has been done using simultaneous IVQREG with a view to obtaining the full covariance matrix of coefficients. This study performs the Wald test on the null hypothesis that income elasticities are the same for the four quantiles. Wald test of F statistic is 6.08, which rejects the null hypothesis that income elasticities are same for the four quantiles. Therefore, income elasticities of water consumption significantly vary across the quantiles.

\section{Summary and Conclusions}

This paper explores water consumption in Dhaka city for better understanding its usage using the 459 household survey data collected by BRAC Institute of Governance and Development (BIGD). For this purpose, we estimated income elasticities of water consumption after controlling the effects of other explanatory variables including wealth-proxies, location, household size, water bill and spatial zones using the instrumental variable regression (IVREG) and instrumental variable quantile regression (IVQREG) approaches for providing more reliable and accurate picture of water usage in Dhaka city.

As most of the households located in Dhaka city use the single source of water, namely Dhaka Water Supply \& Sewerage Authority (DWASA), the estimation of residential water consumption seems to be straightforward. However, imperfect water price information prevailing in the ex post billing in Dhaka city including fixed pay, household-wise water meter, holding-wise water meter, combined water usage with enterprises/businesses etc. make the estimation more complex. Moreover, dearth of facts on water consumption complicate the issue of measuring residential water consumption. However, the basic price theory for water demand from DWASA may still hold to some extent. For example, if the water price is fixed (e.g., fixed water bill) and does not depend on the volume of water usages, the marginal price of water usage is zero for all existing consumers. Hence, the law of demand suggests water use will continue until the marginal utility of water consumption is zero. Hence, preference heterogeneity that persists among the consumers determines the variation in water usage. This rationale is important in our case and it is reflected in our findings that water bill plays 
insignificant role in determining water consumption at the 25 th percentile of water consumption. This is also an indication of weak correlation between fixed pay and water usage. However, this is strongly associated with income. This study uses 'fixed pay for water' an instrumental variable for income. Using the fixed pay variable as instrument, findings reveal the strong evidence that income is endogenous. Therefore, estimates using OLS would suffer from biases. This study contributes in this regard.

The results show that income elasticities are heterogeneous and vary significantly across the water quantiles, implying inequality in income responsiveness to water consumption and it is inversely related with water consumption. The distinctive feature of water consumption is that it is non-linearly related with income. However, findings provide the strong systematic evidence as income elasticity of water consumption decreases with the increase in percentile (i.e., less responsiveness of water consumption to income changes at the higher percentiles). Household income elasticity appears to be inelastic across the distribution and the magnitudes of the income elasticities get smaller as we move to the higher quantiles of water usage. The income elasticity estimate converges to other global estimates as we move from the lowest quantile to the highest water quantile. In our case, water consumption quantiles also reflect the income quantiles in the same direction, but not the same extent. Therefore, our estimate for income elasticities is much wider. This implies strong responsiveness of water consumption to income changes among the water poorest households in Dhaka city. The elasticity estimates obtained for the highest water quantile group are very much consistent with the estimates obtained for other countries (income elasticity of water demand greater than 0.50) such as Bugariam Cyprus, Estonia, Finland, Latvia, Lithunia, Portugal and Slovakia (Reynaud 2015). Note that presence of water meter is significantly higher among the water richest households compared with the water poorest households in Dhaka city, and thus, it has made us possible to accurately measure the income elasticity estimates for Dhaka, which are compatible with the estimates for other countries. However, income elasticity estimates without considering instrumental variables would suffer from downward bias.

Moreover, no water consumption gap between formal and slum settlements persists at the 25 th percentile. However, the gap becomes significant and widens up to 75 th percentile. Then it starts declining. Another important covariate is savings, which is significantly and negatively associated with water usage. In our case, we have used the savings dummy, not the savings amount due to lack of data. Findings using Chi2 statistics show that savings and water consumption are independent, implying no association between them (similar to our OLS findings and correlation matrix). Therefore, our case does not necessarily mean higher water consumption for households with the presence of savings status. The IVQREG model finds the neutral effect of household size on water consumption among the water poorest households (i.e., 25th percentile). However, household size plays a significant role in reducing water consumption, which contrasts with other estimates. This arises because of the heterogeneous household size within a water quantile group. Note that household size is significantly negatively associated with the water consumption and income as well, implying poor income status for a larger household size. Therefore, for a given level of water quantile, household size varies within this water consumption group to reflect the income status. More household members in a family implies the possibility of belonging to a relatively poorer group and thus, the less water consumption.

Significant spatial inequality in water consumption from IVREG approach disappears as we use IVQREG. This also strongly supports the systematic evidence obtained in our 
case for measuring water consumption responsiveness to income changes. Finally, we find that water bill paid has no role in explaining water usage variation at 25 th percentile. However, water bill estimates become significant from the median to upper quantile regressions though the estimates are small in magnitudes, implying the scope to increase the water bill. Moreover, it is evident that water bill has no significant effect on income (Table 4). However, the estimate of water bill is reversed at the 85 th percentile of income. Therefore, introducing increasing tariff blocks (IBT) as water consumption might promote water conservation, ensure more access to water by households belonging to the poor blocks and generate more revenue for the DWASA. However, DWASA must ensure smart water meter to the residents before implementing such tariff structure. Analysis of smart meter traces of individual customers supports prompt detection of leakages (Luciani et al. 2019; Cominola et al. 2019) and other types of anomalies in residential and nonresidential accounts (Patabendige et al. 2018). Further work should seek to collect panel data on price and relevant variables using panel water consumption survey to explore water consumption estimates using quantile regression with instrumental variable for price.

Acknowledgments Authors are thankful to Imran Matin and Mehnaz Rabbani, BRAC Institute of Governance and Development (BIGD), BRAC University for inspiring us to work on this issue and providing us the access to dataset, overall guidelines and feedback as well. We are also thankful and indebted to the two anonymous reviewers and the Editor in Chief of this journal for their invaluable comments.

\section{Compliance with Ethical Standards}

Competing Interests The authors declare that they have no competing interests.

Open Access This article is licensed under a Creative Commons Attribution 4.0 International License, which permits use, sharing, adaptation, distribution and reproduction in any medium or format, as long as you give appropriate credit to the original author(s) and the source, provide a link to the Creative Commons licence, and indicate if changes were made. The images or other third party material in this article are included in the article's Creative Commons licence, unless indicated otherwise in a credit line to the material. If material is not included in the article's Creative Commons licence and your intended use is not permitted by statutory regulation or exceeds the permitted use, you will need to obtain permission directly from the copyright holder. To view a copy of this licence, visit http://creativecommons.org/licenses/by/4.0/.

\section{References}

Abedin SB, Rakib ZB (2013) Generation and quality analysis of greywater at Dhaka City. Environmental Research, Engineering and Management 2(64):29-41. https://doi.org/10.5755/j01.erem.64.2.3992

Agthe DE, Billings RB (1987) Equity, price elasticity, and household income under increasing block rates for water. American Journal of Economics and Sociology 46(3):273-286. https://doi.org/10.1111/j.15367150.1987.tb01966.x

Ahmad S, Mirza MU, Ali S, Lotia H (2016) Analysing household water demand in urban areas empirical evidence from Faisalabad, the industrial city of Pakistan. International growth Centre. https://doi. org/10.13140/RG.2.2.24859.67366

Bartczak A, Kopanska A, Raczka J (2009) Residential water demand in a transition economy: evidence from Poland. Water science and technology: water Supply 9(5):509-516. https://doi.org/10.2166/ws.2009.447

Basani M, Isham J, Reilly B (2008) The determinants of water connection and water consumption: empirical evidence from a Cambodian household survey. World Dev 36(5):953-968. https://doi.org/10.1016/j. worlddev.2007.04.021 
BIGD (2019) Water governance in Dhaka. State of cities 2018. Brac Institute of Governance and Development (BIGD), Brac University

Binet ME, Carlevaro F, Paul M (2014) Estimation of residential water demand with imperfect price perception. Environ Resour Econ 59(4):561-581. https://doi.org/10.1007/s10640-013-9750-z

Bird J, Li Y, Rahman HZ, Rama M, Venables AJ (2018) Toward great Dhaka: a new urban development paradigm eastward. The World Bank

Cameron AC, Trivedi PK (2005) Microeconometrics methods and applications. Cambridge University Press

Cardoso ML (2013) Modeling Portuguese water demand with quantile regression. Doctoral dissertation, University Institute of Lisbon

Chernozhukov V, Hansen C (2005) An IV model of quantile treatment effects. Econometrica 73(1):245-261. https://doi.org/10.1111/j.1468-0262.2005.00570.x

Chernozhukov V, Hansen C (2006) Instrumental quantile regression inference for structural and treatment effect models. J Econ 132(2):491-525. https://doi.org/10.1016/j.jeconom.2005.02.009

Chernozhukov V, Hansen C (2008) Instrumental variable quantile regression: A robust inference approach. J Econ 142(1):379-398. https://doi.org/10.1016/j.jeconom.2007.06.005

Cominola A, Nguyen K, Giuliani M, Stewart RA, Maier HR, Castelletti A (2019) Data mining to uncover heterogeneous water use behaviors from smart meter data. Water Resour Res 55(11):9315-9333. https://doi. org/10.1029/2019WR024897

Crane R (1994) Water markets, market reform and the urban poor: results from Jakarta, Indonesia. World Dev 22(1):71-83. https://doi.org/10.1016/0305-750X(94)90169-4

Dalhuisen JM, Florax RJ, De Groot HL, Nijkamp P (2003) Price and income elasticities of residential water demand: a meta-analysis. Land Econ 79(2):292-308. https://doi.org/10.2307/3146872

Davidson J (2000) Econometric theory. Blackwell, London, Oxford

Deyà-Tortella B, Garcia C, Nilsson W, Tirado D (2019) Hotel water demand: the impact of changing from linear to increasing block rates. Water 11(8):1604. https://doi.org/10.3390/w11081604

Dikgang J, Murwirapachena G, Mgwele A, Girma HM, Simo-Kengne BE, Mahabir J (2019) Insight into setting sustainable water tariffs in South Africa. Water Resource Commission. WRC Report No. 2356/1/19

Espey M, Espey J, Shaw WD (1997) Price elasticity of residential demand for water: a meta-analysis. Water Resour Res 33(6):1369-1374. https://doi.org/10.1029/97WR00571

Flyr M, Burkhardt J, Goemans C, Hans L, Neel A, Maas A (2019) Modeling commercial demand for water: exploring alternative prices, instrumental variables, and heterogeneity. Land economics 1;95(2):211-24

Garcia S, Reynaud A (2003) Estimating the benefits of efficient water pricing in France. Resource and energy economics 26(1):1-25. https://doi.org/10.1016/j.reseneeco.2003.05.001

Gardner K (2010) Residential water demand modelling and behavioural economics, Doctoral dissertation, University of East Anglia

Gaudin S (2006) Effect of price information on residential water demand. Appl Econ 38(4):383-393. https://doi. org/10.1080/00036840500397499

Gaudin S, Griffin RC, Sickles RC (2001) Demand specification for municipal water management: evaluation of the stone-Geary form. Land Econ 77(3):399-422. https://doi.org/10.2307/3147133

Griffin RC (2006) Water resource economics: the analysis of scarcity, policies, and projects. MIT Press Books, 1

Hoffman M, Worthington AC, Higgs H (2006) Urban water demand with fixed volumetric charging in a large municipality: the case of Brisbane Australia. The Australian Journal of Agricultural and Resource Economics 50:347-359. https://doi.org/10.1111/j.1467-8489.2006.00339.x

Koenker R, Bassett G (1978) Quantile Regression. The Econometric Society 46(1):33-50. https://doi. org/10.2307/1913643

Kumar AA, Ramachandran P (2019) Cross-sectional study of factors influencing the residential water demand in Bangalore. Urban Water J 16(3):171-182. https://doi.org/10.1080/1573062X.2019.1637905

Luciani C, Casellato F, Alvisi S, Franchini M (2019) Green smart technology for water (GST4Water): water loss identification at user level by using smart metering systems. Water 11(3):405. https://doi.org/10.3390 /w11030405

Martínez-Espiñeira R (2002) Residential water demand in the northwest of Spain. Environ Resour Econ 21(2): 161-187. https://doi.org/10.1023/A:1014547616408

Nauges C, Strand J (2007) Estimation of non-tap water demand in central American cities. Resour Energy Econ 29(3):165-182. https://doi.org/10.1016/j.reseneeco.2006.05.002

Nauges C, Thomas A (2000) Privately operated water utilities, municipal price negotiation, and estimation of residential water demand: the case of France. Land Econ 76(1):68-85. https://doi.org/10.2307/3147258

Oliveira PJ, Steffen JL, Cheung P (2017) Parameter estimation of seasonal ARIMA models for water demand forecasting using the Harmony Search Algorithm. Procedia Engineering 1(186):177-185 
Patabendige S, Cardell-Oliver R, Wang R, Liu W (2018) Detection and interpretation of anomalous water use for non-residential customers. Environmental Modelling \& Software 1(100):291-301. https://doi.org/10.1016/j. envsoft.2017.11.028

Pokropek A (2016) Introduction to instrumental variables and their application to large-scale assessment data. Large-scale Assessments in Education 4(1):4. https://doi.org/10.1186/s40536-016-0018-2

Reynaud A (2015) Modelling household water demand in Europe-insights from a cross-country econometric analysis of EU-28 countries. In JRC Technical Report EUR 27310 EN, 2015

Rietveld P, Rouwendal J, Zwart B (2000) Block rate pricing of water in Indonesia: an analysis of welfare effects. Bull Indones Econ Stud 36(3):73-92. https://doi.org/10.1080/00074910012331338983

Romano G, Salvati N, Guerrini A (2016) An empirical analysis of the determinants of water demand in Italy. J Clean Prod 130:74-81. https://doi.org/10.1016/j.jclepro.2015.09.141

Sebri M (2016) Forecasting urban water demand: A meta-regression analysis, Journal of Environmental Management xxx (1-9). https://doi.org/10.1016/j.jenvman.2016.09.032-

Saleth RM, Dinar A (2000) Urban thirst: water supply augmentation and pricing policy in Hyderabad city India. The World Bank Technical Paper 2000:395

Schleich J, Hillenbrand T (2009) Determinants of residential water demand in Germany. Ecol Econ 68(6):17561769. https://doi.org/10.1016/j.ecolecon.2008.11.012

Stevens TH, Miller J, Willis C (1992) Effect of price structure on residential water demand. Water Resour Bull 28(4):681-685. https://doi.org/10.1111/j.1752-1688.1992.tb01489.x

Strand J, Walker I (2005) Water markets and demand in central American cities. Environ Dev Econ 10(03):313335. https://doi.org/10.1017/S1355770X05002093

United Nations, Department of Economic and Social Affairs, Population Division (2018). The World's Cities in 2018-Data Booklet (ST/ESA/ SER.A/417). United Nations, 2018

United Nations-Habitat (2017). Urban Data: Dhaka, urban agglomeration population density (population $/ \mathrm{km}^{2}$ ) in 2013. Available at: htt://urbandata.unhabitat.org/data-city/?citis=6081\&indicators=urban_agglomeratin populatin density. Accessed 30 March 2019

WASA (2016) Annual report 2015-16. Dhaka water supply and sewerage authority, Dhaka, Bangladesh

Wentz EA, Gober P (2007) Determinants of small-area water consumption for the City of Phoenix, Arizona. Water Resour Manag 21(11):1849-1863. https://doi.org/10.1007/s11269-006-9133-0

Worthington AC, Hoffman M (2008) An empirical survey of residential water demand modelling. J Econ Surv 22(5):842-871. https://doi.org/10.1111/j.1467-6419.2008.00551.x

Publisher's Note Springer Nature remains neutral with regard to jurisdictional claims in published maps and institutional affiliations.

\section{Affiliations}

\section{Muhammad Shahadat Hossain Siddiquee $^{1,2} \cdot$ Raihan Ahamed $^{1}$}

1 BRAC Institute of Governance and Development, BRAC University, Dhaka, Bangladesh

2 Department of Economics, University of Dhaka, Dhaka, Bangladesh 